\title{
Policies, administration, and management
}

\author{
Melody M. Thompson \\ 314 Keller Building (mail) \\ The Pennsylvania State University \\ University Park, PA 16802 \\ mmt2@psu.edu
}

ABSTRACT. The chapters in this section focus on the ways in which policies encourage or hamper the integration of distance education into mainstream educational institutions. The authors provide insights and perspectives into the key policies, roles, structures, processes, and standards that characterize the rapidly changing educational environment. The information in this chapter will be useful to distance education practitioners and leaders in responding to current challenges and in proactively influencing future change.

RÉSUMÉ. Les chapitres de cette section du "Handbook» portent sur la façon dont les politiques encouragent ou contrecarrent l'intégration de l'enseignement à distance dans les institutions d'enseignement supérieur classiques. L'auteur fournit aperçus et perspectives concernant les principales stratégies, les rôles, les structures, processus et normes qui caractérisent un contexte éducatif en rapide évolution. Les informations de ces chapitres seront utiles aux praticiens de l'enseignement à distance et aux décideurs pour réagir face aux défis actuels et pour influer de façon proactive les changements à venir.

KEYWORDS: institutional policy structures, leadership, participation by teaching staff, legal issues, quality standards, evaluation.

MOTS-CLÉS: structures potitiques institutionnelles, leadership, pouvoir décisionnel, participation des enseignants, enjeux juridiques, normes et qualité, évaluation.

DOI:10.3166/DS.7.627-641 @ Cned/Lavoisier

D\&S - 7/2009. À la croisée des recherches, pages 627 to 641 


\section{Introduction}

Distance teaching and learning occur within an institutional administrative structure that can either encourage and support these activities or marginalize and hamper them. The institution's "stance" toward distance education is reflected in its policies, which guide, encourage, and/or constrain the actions of its members.

Institutional policies define distance education's place within the institutional structure and reward system and as such signal to participants and non-participants alike the value placed on the activity itself, as well as on those who are engaged in it. As distance education has moved from the margins to the "mainstream" of institutional goals and programs, a number of administrative and policy issues have become the focus of institutional planning and academic research.

The chapters in this section focus on some of these issues both generally and specifically. Several themes appear in multiple chapters, reflecting the interrelatedness of these issues even as the focus shifts from one topic to another. For example, the need for a clear and integrated overall policy structure identified by Michael Simonson is illustrated more specifically in Wolcott and Shattuck's chapter on faculty participation and in Michael Lipinski's overview of legal issues related to copyrighted material. Issues of program and institutional quality are even more broadly reflected in this section: in Michael Simonson's chapter on the policies necessary to promote program quality, Michael Beaudoin's chapter on the type of leaders who can ensure the quality of emerging institutional structures, Amy Lezberg's chapter on the development of uniform measures of program quality, and Melody Thompson and Modupe Irele's chapter on evaluation as a source of information for both measuring and ensuring program quality.

Individually and as a group, the authors in this section address key issues in the integration of distance education into the educational "mainstream." The questions they raise and the answers they suggest will be of use to educators in many contexts and at many levels of the educational system.

\section{Chapter 28: Institutional policy issues}

Focusing primarily on K-12 programs, Michael Simonson starts off this section by explaining the importance of clear and comprehensive institutional policies, reviews previous work related to distance education policy, and proposes a framework to guide the development of policies in public and private organizations.

Distance education policy is "the written course of action adopted by institutions to facilitate the development of distance education programs" (p. 355). Policies are necessary to delineate roles, responsibilities, and standard operating procedures. According to Simonson, establishing a policy framework is necessary for the successful introduction an innovation such as distance education into an existing 
organization, and development of policies is a step that both signals and encourages acceptance. Policies are especially important in regulating relationships when schools or school systems collaborate in offering distance education programming.

Based on a review of the policy models proposed by Berge (1998) and GellmanDanley and Fetzner (1998) and the analyses of other researchers (King, Nugent, Russell, et al., 2000), Simonson identifies seven categories of distance education policies:

1. Academic policies regulate the overall integrity of the course in the areas of students, instruction, and curriculum.

2. Fiscal, geographic, and governance policies address ownership of the course, responsibility for various costs, revenue distribution, geographic service areas, and oversight responsibility.

3. Faculty (teaching staff) policies cover compensation, class size, incentives for designing courses, staff development, academic freedom, and integration with traditional labor-management structures.

4. Legal policies focus on intellectual property issues, copyright, and liability for inappropriate use of telecommunications networks.

5. Student policies regulate the provision of support services and feedback to students from instructors.

6. Technical policies address responsibility for the reliability of the communications network and hardware, software, and connectivity requirements for students.

7. Philosophical policy aspects reflect the vision, mission and understanding of distance education activities by the educational institution offering or receiving distance education programs.

Following a discussion of each of the seven policy categories, the author provides examples for each category from actual policy documents developed by state systems of education or local school districts. These examples provide a basis for his final recommendation, which relates to the crucial function of integration: "Initially, distance education policies will probably need to be infused with existing policies. Ultimately, they should be integrated to indicate that distance education is a routine and regularly occurring component of the educational enterprise" (p. 361).

\section{Chapter 29: Strategic planning}

Whether or not distance education policies are ultimately integrated into the institution's overall policy framework to some extent will depend on strategic planning. Although most educators recognize the importance of strategic planning, authors Ryan Watkins and Roger Kaufman argue that there is an important prior step that is usually not considered part of the strategic planning process: determining whether a distance education solution is appropriate for the particular problem the 
institution is trying to solve. Citing Rumble's (1986) insight that "too often those charged with setting up a distance education system are not given the choice to recommend against it," the authors propose that the first step in a "pragmatic planning" approach should be a rigorous needs assessment to provide information necessary to justify later difficult decisions related to the significant expenditures of time, money, and other resources.

Watkins and Kaufman cite several models of systemic-needs assessment used to identify and prioritize needs at the societal, institutional, and/or individual levels. They focus particularly on Kaufman's approach $(2000,2006)$ for its alignment of the strategic planning, tactical decision-making, and needs assessments processes with these three levels of needs.

According to the authors, three principles should guide needs assessment: 1) Distance learning is a means for achieving an institutional goal, not an end in itself; 2) Desired results need to be prioritized; and 3) The concept of "need" must be understood as a gap in results, not as a desire for a program or initiative. The authors suggest a five-step needs assessment model to guide strategic planning:

- Step One: Identify and Align the Institution's Vision and Mission.

- Step Two: Identify the Needs. Use qualitative and quantitative data to identify the gap between current performance and the level of performance necessary to accomplish the results identified in Step One.

- Step Three: Prioritize and Select Need(s) to be Assessed. Data collected in the first two steps is used in comparing the cost of meeting the needs (closing the gaps) against the cost of not meeting the needs.

- Step Four: Identify Solution Requirements and Alternative Solutions. Establishing criteria that define the requirements of a viable solution and the basis on which possible solutions (including distance education) will be judged allows a comparison of the strengths and weaknesses of each possible solution.

- Step Five: Selecting the Solutions(s) From Among Alternatives. A combination of solutions is often the best option. The data from the needs assessment, rather than cost and political pressure, should suggest the most appropriate solution.

Watkins and Kaufman challenge educators to take a proactive perspective on strategic planning in order to create an institutional future that "focuses on the required skills and knowledge for learners to attain long-term success and quality of life" (p. 373). The authors end by identifying nine areas in which research related to needs assessment and strategic planning is needed.

\section{Chapter 30: Faculty participation: motivations, incentives, and rewards}

What are the strategic needs related to faculty (teaching staff)? Why do faculty members participate in distance education? What encourages them or discourages 
them from involvement? These are three of the questions Linda Wolcott and Kay Shattuck address in their review of faculty participation issues in distance education.

The authors begin with a discussion of intrinsic motives, those that result when the activity or some aspect of the activity has an inherent appeal. Researchers (e.g., Wolcott and Betts, 1999) have identified five types of intrinsic motives related to participation in distance education: satisfaction, growth, challenge, altruism, and career enhancement. Intrinsic motives are reported by researchers across disciplines and institutions to be the most influential factors in faculty decisions to participate (Cook, 2003).

Extrinsic motives, on the other hand, result from external influences and include institutional expectations and encouragement and/or support. Expectations take the form of considering online teaching as part of the normal workload, and encouragement and support can take the form of extra financial compensation for teaching beyond the normal workload, equipment, release from traditional teaching, and credit toward promotion or tenure.

Wolcott and Shattuck report differences between faculty and administrators as to what motivates faculty to teach on line. Whereas faculty responses emphasize intrinsic motives, administrators are more likely to believe that external motives such as monetary support, increase in salary, credit toward promotion or tenure, or release from traditional teaching assignments motivate faculty to participate (Schifter, 2000; O'Quinn and Corry, 2004).

Another discrepancy is apparent between those who do participate in distance education and those who do not. Participants emphasize the importance of intrinsic motives, while non-participants speculate that extrinsic motives would be more likely to convince them to participate (Edwards, 2001).

External factors influence motives for participation. Enhancers lower the barriers to participation and include the availability of support services such as technical support, instructional design support, and student support services. Enhancers also influence satisfaction with distance teaching (Lee, 2001; Shea, Pickett, and Li, 2005). An enhancement missing from many institutional support structures, but reported by faculty as important, is adequate technical/pedagogical training. Wolcott and Shattuck again report a discrepancy: Whereas faculty may not feel adequately supported, administrators believe that adequate instructional support is provided.

Inducements encourage participation and include adjustments to work load, supplemental compensation, money for travel or equipment, training grants, and staff support. The authors note that while the importance of such factors has been widely noted among both faculty and administrators, structures and procedures for offering them have not been broadly implemented (Pina, 2005).

The authors name five consistently cited contextual barriers that discourage participation: lack of 1) time, 2) compensation, 3) incentives and/or rewards, 4) 
policies, and 5) institutional support. Lack of time and lack of compensation were reported to be the greatest obstacles to participation (Berge and Muilenburg, 2001).

Rewards for online teaching are largely intrinsic: professional growth, improvement of technology skills, and skills that can be applied to classroom-based instruction (Hagovsky, 2002). Few examples of extrinsic rewards - those through with institutions formally recognize faculty efforts - are reported in the literature. Of particular importance for faculty is the impact of distance teaching on tenure and promotion. Given the current evidence that such activities seldom contribute to career advancement (Hagovsky, 2002) and therefore inhibit participation (Porter, 2003) one recommendation is reform of the institutional reward system (Lindquist, 2004).

The success of distance education depends on the commitment of the teaching faculty. The authors suggest that further research on and attention to the factors that encourage and discourage participation will maximize the reach and impact of distance education programs.

\section{Chapter 31: Institutional leadership}

Attending to the issues identified so far in this section will be the responsibility of institutional leaders. Yet, as Michael Beaudoin argues, while considerable attention has been given to changes in faculty roles brought about by the proliferation of technology-assisted instruction, little emphasis has been put on the changing roles of distance educational leaders. He distinguishes the leadership function from the managerial function, noting that leaders "create conditions for innovative change" (p. 391).

Leaders in higher education are called to shape the institutional changes driven by technological innovation, particularly the industrialization of higher education. Beaudoin cites Peters' (1994) observation that distance educators have for years reflected an entrepreneurial spirit in their practice through «division of labor, marketing, quality control, and other measures that are more akin to operating a business than overseeing an academic enterprise" (p. 393). These are the elements that will need to be managed in the networked institutions that result from the convergence of distance education and traditional institutions.

Beaudoin reports that while considerable research has focused on legitimizing distance education, there has been little attention in the literature to leadership, particularly to the leadership qualities and actions associated with growth and success. He noted two exceptions to this otherwise disappointing situation: the Online Journal of Distance Learning Administration published by West Georgia State University and the papers presented at this university's national conference.

Three recently published books are cited for their substantial contributions to the distance education leadership discourse: the Handbook of Distance Education in which these chapters appear; Hanna and Latchem's (2001) Leadership and 
Management in Open and Flexible Learning; and Beaudoin's own work, Reflections on Research, Faculty, and Leadership in Distance Education (2004).

What leadership style is most suitable to the task of assessing stakeholders readiness for change and the reshaping entrenched educational practices? Beaudoin sees promise in a combination of the transformative leadership (Bennis and Nanus, 1985) and situational leadership (Hersey, Johnson, and Blanchard, 2001) approaches.

Beaudoin suggests that one of the most critical questions likely to be faced by distance education leaders is whether to promote a central or distributed distance education unit. Both approaches have benefits and drawbacks in promoting long-term institutional integration, and leaders' assessments and advice as to which option to pursue "will test their credibility and influence within their organization » (p. 400).

Effective participation with other leaders at the "macro" level of the institution as a whole must not be at the expense of effective practice in the "micro" environment of the distance education function. The "formidable repertoire of skills" needed at the latter level include "needs assessment, market analysis, strategic planning, fitting technology to needs, operationalizing ideas, resource mobilization, introducing online infrastructure, policy formulation, training and support for faculty, collaborating with partner, program evaluation and accreditation, and mentoring the next generation of leaders" (p. 401). This somewhat daunting list of responsibilities underlines Beaudoin's final point: the necessity for a shift in leadership focus from a narrow focus on issues of technology and its impact on learners to a wider view of both the distance education function and its impact in the larger institutional context.

\section{Chapter 32: Accreditation: quality control in higher distance education}

One of the most important challenges facing distance education institutions and leaders is building confidence in program quality. Amy Lezberg begins her chapter by noting a major difference between the United States and other countries in the world: The quality of post-secondary educational institutions is regulated not by a central Ministry of Higher Education but rather by a combination of distributed governmental and non-governmental agencies. Governmental oversight is provided through licensing at the state level, and among the 50 states such oversight ranges from minimal to stringent. In the face of such variation, private accreditation associations were created to provide a more consistent level of quality assurance.

The most prominent of these agencies are the six regional accrediting agencies, which accredit approximately 3,5000 public and private, non-profit and for-profit post-secondary institutions. Oversight is determined largely by the geographic location within which an institution is chartered.

In the early years of distance education, quality assurance was provided not by these accrediting agencies, but rather by three other groups: The Distance Education 
and Training Council, the American Council on Education, and consortia such as the Western Interstate Commission for Higher education. However, as the reach and impact of distance education programming increased, the regional accrediting associations began to turn their attention to developing criteria for assuring the quality of distance - particularly online - programs.

The associations faced unfamiliar challenges: determining the place of geographic regionalism in the developing distance education environment; ascertaining which aspects of a residential education were central to educational quality and alternative ways of measuring whether they had been achieved in a nonresidential program; and identification and training of those who would evaluate and enforce quality standards. Initially unwilling to yield their regional sovereignty, the six associations moved only slowly toward complete integration of standards. An initial step was formation of a task force to develop a joint statement of expectations. The accrediting bodies had earlier surveyed their members to identify concerns related to distance education programs. The most frequently mentioned concerns were insuring the integrity of the degree, cost and accessibility for students and institutions; interaction among students and faculty; faculty development; faculty issues such as compensation, workload, and intellectual property rights, student access to academic support services, and technical training and support for students and faculty. The task force ultimately recommended guidelines that were accepted by all the accrediting commissions, who implemented them with modifications that reflected differences among institutions.

Within two years the regional commissions realized that they needed a single document implemented uniformly and without modifications. The result was "Best Practices for Electronically Offered Degree and Certificate Programs" (see http://www.ncahlc.org/download/Best_Pract_DEd.pdf). Five categories of institutional activity are addressed: institutional context and commitment; curriculum and instruction; faculty support; student support; and evaluation and assessment. Statements of principle addressing each activity are followed by questions to assist in assessing whether key elements of each activity are represented in the program.

Lezberg notes that although these legitimate commissions are successfully ensuring the quality of distance education programs, a number of privately formed "accreditation mills" have to some extent undermined international confidence in distance education programs. However, she is hopeful that the current rigorous approach the accrediting agencies are taking to quality assurance will become universally recognized as a guarantee of high quality post-secondary education.

\section{Chapter 33: Evaluating distance education programs}

Quality control and evaluation of programs are closely connected. Melody Thompson and Modupe Irele begin their examination of the evaluation function by describing how the context for evaluation has changed. In the past, distance 
education operated on the margins of traditional institutions and evaluations were intended to legitimize this activity by demonstrating that learning was possible in a distance format. Distance education activities are now more often viewed as a core institutional function. As such they are challenging the "core academic values...central to the history and tradition of higher education (Eaton, 2000, cited on p. 420). Given this challenge to values, and the speed with which it is occurring within "even the most cautious and conservative of universities...the case for researching and evaluating the applications of these new technologies is obvious" (Bates, 2000, cited on p. 420). However, Thompson and Irele caution, to be useful in guiding the institutional transformation that online learning portends, evaluation studies must be rigorously planned and executed.

According to the authors, evaluations are conducted for four main purposes: to a) to justify institutional investment; b) to track progress toward institutional goals; c) to guide program improvement; and d) to provide information for future planning. These purposes can only be served when the evaluation activity is well-designed and appropriately supported by institutional leadership.

Thompson and Irele review program evaluation models from both traditional and distance education. The former group is represented by Stufflebeam's (1999) Foundational Models for 21st Century Program Evaluation and The Program Evaluation Standards (Joint Committee on Standards for Educational Evaluation, 1994). "What the Program Evaluation Standards Say about Designing Evaluations," a document derived from the latter publication, synthesizes many sources of advice on designing evaluations and is available on line at http://www.wmichedu/ evalctr /jc/DesigningEval.htm.

The authors highlight several evaluation approaches developed specifically for distance education. Duning, Van Kekerix, and Zaborowski (1993) propose evaluation at three levels: the functional (technical-design), the managerial (relationships within and outside the organizational structure), and the instructional or ethical (choices related to program outcomes). Ehrmann (1999), in association with the American Association of Higher Education's Teaching, Learning, and Technology (TLT) Group, has developed a comprehensive "Tool Kit" to guide evaluators. The ACTIONS model (Bates, 2000) focuses attention on Access and flexibility, Costs, Teaching and learning, Interactivity and user friendliness, Organizational issues, Novelty, and Speed. Finally, Lockee, Moore, and Burton (2002) offer an "incremental" model based on stages of program development and delivery and data collection methods appropriate for each stage.

Thompson and Irele conclude by noting two promising trends: development of clearly articulated standards for distance education programs and research on the evaluation process. The former is represented by incorporation of quality guidelines into the evaluation guide used by all eight regional accrediting agencies for higher education institutions. The latter is represented by two meta-analyses of quality criteria (Institute for Higher Education Policy, 2000; Frydenberg, 2002)) and an 
international Delphi study (Mariasingham (2005) on quality criteria for online degree programs. What is still lacking, the authors suggest, is a focus on "how disparate aspects of a program actually fit together" (Ewell, 1998, cited on p. 432) and evaluations that go beyond the program level of distance education activities to the institutional, national, and even the international level of programming.

\section{Chapter 34: Comparing costs of alternative delivery methods}

Pressure to evaluate and maintain quality is one aspect of the current distance education context; another is the mounting pressure to provide post-secondary education more cost effectively. Alistair Inglis reports that in many countries, this has involved investigation of the benefits, particularly the cost benefits, of a shift from classroom-based learning to resource-based learning. Whereas classroom-based learning emphasizes student-instructor and student-student interactions, resourcebased learning occurs via student interaction with learning materials and other resources. The latter approach offers significant economies of scale and savings in recurrent costs.

Inglis explains that educational economies of scale result from spreading fixed costs (those independent of output) over a larger number of student enrollments. Economies of scale can be obtained by a) spreading the costs of course design and development over larger numbers of students in each course and/or b) spreading the costs of the institutional infrastructure over larger numbers of students enrolled in the institution. This is the model successfully implemented by the U.K. Open University and emulated in a number of other countries.

In the United States, Twigg (1994) has been a major proponent of the resourcebased approach. However, to date implementation of distance education programs has occurred by expanding the classroom-based model beyond the institution via communications technologies (first audio and video, then Internet and Web-based).

Inglis discusses a number of factors important in understanding the cost aspects of distance delivery. First is the difficulty in comparing the actual costs of different delivery systems, which is complicated by the variability of these costs from country to country and within a given country. Other complications in comparing actual costs are identifying the relative impact of each cost variable and in choosing the benefits to be analyzed in a cost-benefit analysis.

Two important principles in any cost comparison are understanding how costs inter-relate and comparing "like with like." It should not be assumed that two different delivery systems will result in the same benefits, nor should it be assumed that more complicated delivery systems (and higher development costs) necessarily result in additional benefits.

An important factor in any cost analysis are the hidden costs that accrue to the institution, the staff, or students. Hidden institutional costs remain unaccounted for 
largely because of the difficulty in getting faculty and staff to comply with "time tracking" policies. Many hidden costs to students result from institutions' tendency to shift an increasing number of costs - communications charges, document printing, etc. - to students.

In business contexts, costs are typically borne by the employer and can often be greatly reduced by replacing face-to-face training with online training (Ravet and Layte, 1997). The value of a training experience is generally measured by return on investment (ROI), and the ROI for different alternatives can be calculated and compared. Training managers generally think of "return" as attainment of training; however, business unit managers are more likely to consider improvements to business outcomes attributable to the training (Cross, 2001).

In answer to the question "How can the costs of delivery best be managed?", given a decision to go online, Inglis suggests a focus not on delivery system components, but rather on delivery models that blends resource-based and classroom-based approaches. This blended approach will again change the costing environment, raising new questions that focus on containing costs while maintaining educational quality in a hybrid environment.

\section{Chapter 35: Legal issues in the development and use of copyrighted material}

The final contextual factor discussed in this section is the developing legal environment for distance education programs. Tomas Lipinski takes us among the intricate and in some cases still unresolved issues of ownership and use rights related to copyrighted material. New legal regulations have accompanied the expansion of educational programs into Web-based environments and the subsequent development and/or use of copyrighted materials in virtual, rather than physical, classrooms. The intent of these regulations is to support use while encouraging compliance with prior and new copyright law. However, there remains considerable controversy over the ownership and control of materials that faculty create in support of their distance teaching.

Issues relating to a determination of ownership include whether the materials were created as 'work made for hire' (in which case ownership resides with the university) or whether they reflect a teaching or 'lecture-note' exception to this provision (in which case the material belongs to the faculty member). Another issue is whether there is a 'scholarship' exception based on faculty members' broader academic responsibilities in Web-based environments.

Much of the 'work made for hire' controversy centers around the question of whether a faculty member should be considered an 'employee' of the institution, and indeed legal precedent suggests a well-recognized teaching exception in higher education (Kulkarni, 1995; Lape, 1992). However, Lipinski reports that question of a scholarship exception is still the subject of controversy, as reflected in conflicting 
legal decisions. The author reviews of number of these decisions to illustrate the extent of ongoing controversy and concludes that the issue must ultimately be resolved by federal legislative reform or consideration and a decision by the Supreme Court.

Lipinski explains the three types of liability under copyright law:

- Direct infringement is the violation of one of the exclusive rights of the copyright owner (reproduction, public display or transmission; derivative works) in excess of any fair use or other legal limits.

- Contributory infringement occurs when someone knowingly encourages another to infringe copyright, as when a faculty member directs students to sites with infringing material.

- Vicarious infringement occurs when someone under another's supervision (such as a lower-level employee) infringes copyright. The responsibility is vested in the supervisor, not the employee.

Suits for damages can be brought against individuals or institutions that infringe on copyrights. Lipinski reviews several "damage enhancement and remission" provisions of copyright law that serve to lessen the penalties courts impose (Lipinski, 2006). Perhaps the most important of these are those dealing with expectation of institutional actions to limit and respond to infringements. These include adoption, implementation, and publication of a copyright compliance policy; provision to employees of a basic education in copyright law; and development and implementation of a policy to terminate repeat infringers. Additional topics covered in the chapter are performance and display rights and recording rights. Although these rights were expanded under the recent TEACH (Technology, Education, and Copyright Harmonization) Act, they are in some cases more strictly regulated.

\section{Conclusion}

The overarching theme in these articles is change: change that has already occurred and further changes that need to be made in policies, roles, structures, processes, and standards. The ability of distance education leaders - those at the official "leadership" level as well as those in other positions of influence - to respond to and proactively shape the these changes will determine the extent to which the transformative potential of distance education is realized in the years to come.

\section{References}

Bates A. W. T., 2000. Managing technological change. Strategies for college and university leaders, San Francisco: Jossey-Bass. 
Beaudoin M., 2004. Reflections on research, faculty, and leadership in distance education, Oldenburg, Germany: Oldenburg University Press.

Bennis W. and B. Nanus, 1985. Leaders: The strategies for taking charge, New York: Harper and Row.

Berge Z., 1998. "Barriers to online teaching in post-secondary institutions: Can policy changes fix it?", Online Journal of Distance Learning Administration, I(2). http://www.westga.edu/ distance/Berge12.html

Berge Z., and L. Muilenburg, 2001. "Obstacles faced at various stages of capability regarding distance education in institutions of higher education", TechTrends, 45, p. 40-45.

Cook R. G., 2003. "Factors that motivate or inhibit faculty participation in distance education: An exploratory study", Dissertation Abstracts International, 64(06), 1953A. (UMI No. AAT 3049007).

Cross J., 2001. “A fresh look at ROI”, Learning Circuits, American Society for Training and Development. http://www.internettime.com/Learning/articles/Learning\%20Circuits.htm

Duning B. S., M. J. Van Kekerix, and L. M. Zaborowski, 1993. Reaching learners through telecommunications, San Francisco: Jossey-Bass.

Eaton J. S., 2000. Core academic values, quality, and regional accreditation: The challenge of distance learning, Washington, DC: Council for Higher Education Accreditation.

Edwards Y. V., 2001. "Rehabilitation education faculty motivation toward distance education: A national study of CORE rehabilitation faculty", Dissertation Abstracts International, 62(06), 2035A. (UMI No. AAT 3018573).

Ehrmann S. C., 1999. Studying teaching, learning and technology: A tool kit from the Flashlight Program. http://www.tltgroup.org/resources/fstudtool.html

Ewell P., 1998. Examining a brave new world: How accreditation might be different. Council for Higher Education Accreditation. http://www.chea.org/Events/ Usefulness/98May/98 05Ewell.html

Gellman-Danley B., and M. Fetzner, 1998. "Asking the really tough questions: Policy issues for distance learning", Online Journal of Distance Learning Administration, I(1). http://www.westga.edu/ distance/danley11.html

Hagovsky T. C., 2002. "Factors affecting the implementation of distance education initiatives in the Indiana Partnership for Statewide Education", Dissertation Abstracts International, 64(08), 2802A. (UMI No. AAT 3099152).

Hanna D. and C. Latchem, 2001. Leadership and management in open and flexible learning. London: Kogan Page.

Hersey P., D. Johnson, and K. Blanchard, 2001. Management of organizational behavior: Leading human resources, Englewood Cliffs, NJ: Prentice Hall.

Institute for Higher Education Policy, 2000. Quality on the line. Benchmarks for success in Internet-based distance education, Washington, DC: Institute for Higher Education Policy. 
Joint Committee on Standards for Educational Evaluation, 1994. The program evaluation standards. How to assess evaluations of educational programs, Thousand Oaks, CA.: Sage.

Frydenberg J., 2002. "Quality standards in e-learning: A matrix of analysis", International Review of Research in Open and Distance Learning 3(2). http://www.irrodl.org/index. $\mathrm{php} / \mathrm{irrodl} /$ article/view/109/551.

Kaufman R., 2000. Mega planning: Practical tools for organizational success, Thousand Oaks, CA: Sage.

Kaufman R., 2006. Change, choice, and consequences: A guide to mega thinking and planning, Amherst, MA: HRD Press.

King J., G. Nugent, E, Russell, J. Eich, and D. Lacy, 2000. "Policy frameworks for distance education: Implications for decision makers", Online Journal of Distance Learning Administration, 3(2). http://www.westga.edu/ distance/king32.html

Kirk J. J., and H. Shoemaker, 1999. "Motivating community college instructors to teach online: An exploration of selected motivators", Academy of Human Resource Development (AHRD) Conference Proceedings (311-317). (ERIC Document Reproduction Service No. ED 431942).

Kulkarni S. R. 1995. “All professors create equally: Why faculty should have complete control over the intellectual property rights in their creation", Hastings Law Journal, 47, 221-256.

Lee J., 2001. "Institutional support for distance education and faculty motivation, commitment, satisfaction”, British Journal of Educational Technology, 32(2), 153-160.

Lindquist S. L., 2004. "With a map and compass: Planning for the online journey", Dissertation Abstracts International, 65(11), 4129A. (UMI No. AAT 3154782).

Lipinski T. A. 2006. The complete copyright liability handbook for librarians and educators. New York: Neal-Schuman.

Lockee B. B., J. K. Burton, and L. H. Cross, 1999. "No comparison: Distance education finds a new use for 'No Significant Difference'". Educational Technology Research \& Development, 47(3), 33-44.

Mariasingham 2005. Findings of the Delphi Study on quality criteria and benchmarks for online degree programs. http://www.odlaa.org/resources/DelphistudyResults Summary .pdf

O'Quinn L. R., and M. Corry, 2004. "Factors which motivate community college faculty to participate in distance education", International Journal of E-Learning, 3(1), 19-30.

Peters O. 1994. Otto Peters on distance education: The industrialization of teaching and learning. In D. Keegan (Ed.), Foundations of distance education (pp. 77-88). London: Routledge.

Pina A. A., 2005. "Distance learning: The importance and implementation of factors affecting its institutionalization", Dissertation Abstracts International, 66(03), 970A. (UMI No. AAT 3168540). 
Porter R. D., 2003. "Internet-based distance educators address major distance education barriers in large postsecondary institutions", Dissertation Abstracts International, 65(04), 1278A. (UMI No. AAT 3130048).

Ravet S., and M. Layte, 1997. Technology-based training. A comprehensive guide to choosing, implementing and developing new technologies in training. London: Kogan Page.

Regional Accrediting Commissions. 2001. Best practices for electronically offered degree and certificate programs. http://www.ncahlc.org/download/Best_Pract_DEd.pdf

Schifter C. C., 2000. "Faculty motivators and inhibitors for participation in distance education", Educational Technology, 40, 43-46.

Shea P., A. Pickett, and C. S. Li. 2005. "Increasing access to higher education: A study of the diffusion of online teaching among 913 college faculty", International Review of Research in Open and Distance Learning, 6(2). http://www.irrodl.org/index.php /irrodl /article/view/238/493

Stufflebeam D. L.1999. Foundational models for 21st century program evaluation. The Evaluation Center, Western Michigan University.

Twigg C. A. 1994. The need for a National Learning Infrastructure. EDUCOM Review, 29(4, $5,6)$.

Wolcott L. L., and K. S. Betts. 1999. "What's in it for me? Incentives for faculty participation in distance education", Journal of Distance Education, 14(2), 34-49. 
